\title{
Acute rhabdomyolysis following epidural steroid injection: An unusual complication in a patient with low back pain
}

\author{
Kronik bel ağrılı hastada nadir görülen bir komplikasyon: \\ Epidural steroid enjeksiyonunu takiben gelişen akut rabdomiyoliz
}



\begin{abstract}
Summary
Epidural steroid injection is a very common intervention in the treatment of low back pain and sciatic symptoms. The most common complication for epidural steroid injection is transient headache with or without identifiable dural puncture. Other complications have also been reported, including intravascular entry, local hematoma, bleeding, increased back pain, facial flushing, vasovagal reactions, nausea, and fever. We report a case of rhabdomyolysis following epidural steroid injection for lumbar radiculopathy.
\end{abstract}

Keywords: Epidural steroid injection; low back pain; rhabdomyolysis; serum creatinine kinase; serum myoglobin.

\begin{abstract}
Özet
Epidural steroid enjeksiyonu kronik bel ağrısında yaygın kullanılan bir tedavidir. Epidural steroid enjeksiyonun en sık görülen komplikasyonu, dural yırtığın eşlik ettiği yada etmediği çoğunlukla geçici olan baş ağrısıdır. Gözlenen diğer komplikasyonlar arasında; intravasküler enjeksiyon, lokal hematom, kanama, bel ağrısında artış, yüzde flushing, vazovagal reaksiyonlar, bulantı ve ateş bildirilmiştir. Bu olgu sunumunda lumber radikülopatiye bağlı kronik bel ağrısı olan hastaya uygulanan epidural steroid enjeksiyonunu takiben gelişen akut rabdomiyolizi sunduk.
\end{abstract}

Anahtar sözcükler: Epidural steroid enjeksiyonu; bel ağrısı; rabdomiyoliz; serum kreatin kinaz; serum miyoglobin.

\section{Introduction}

The most common complication for epidural steroid injection is transient headache with or without identifiable dural puncture. Other complications have also been reported including intravascular entry, local hematoma, bleeding, increased back pain, facial flushing, vasovagal reactions, nausea and fever. ${ }^{[1]}$ There are a lot of published reports of complications following epidural steroid injections in the literature but rhabdomyolys is not reported yet.

Rhabdomyolysis is a clinical and biochemical syndrome that is induced by metabolic or structural abnormalities of skeletal muscles. Elevated levels of creatine kinase is the biochemical marker of rhabdomyolysis. Arrhythmias, electrolyte abnormalities, acute renal injury, acidosis, volume depletion, compartment syndrome and disseminated intravascular coagulation are the complications. ${ }^{[2]}$ The prognosis is highly variable and depends on the complications. We report about a very unusual, but emergent cause of rhabdomyolysis due to lombal epidural steroid injection.

\section{Case Report}

The patient was a 47 years old female. She had worsened left-sided sciatic pain secondary to the lumbar disc prolapse at L5/S1 level. Patient had no constitutional symptoms or red-flag signs. Pre- injection, the clinical examination revealed a slight altered sensation in the left L5 and S1 dermatome with normal motor examination. Routine haematological investigations were normal and negative for infections. She

\footnotetext{
'Department of Algology, Yüksek İhtisas Training and Research Hospital, Bursa, Turkey 2Department of Algology, Numune Training and Research Hospital, Adana, Turkey ${ }^{3}$ Department of Algology, Ankara University Faculty of Medicine, Ankara, Turkey

Correspondence: Dr. Damla Yürük. Bursa Yüksek ihtisas Eğitim ve Araştırma Hastanesi, Algoloji Kliniği, 16290 Bursa, Turkey.

Phone: +90 - 531 - 9932378 e-mail: damlayuruk@hotmail.com

(C) 2018 Turkish Society of Algology

Submitted (Başvuru tarihi) 29.11.2016 Accepted after revision (Düzeltme sonrası kabul tarihi) 30.09.2017 Available online date (Online yayımlanma tarihi) 11.10.2018 
had been seen by the pain physician for chronic radicular back pain and fluoroscopically guided posterior epidural and transforaminal steroid (dexamethasone $8 \mathrm{mg}$ ) was performed. No adverse events occurred during interventional procedure. Patient stated that her complaints started one hour following lombal epidural steroid injection. She presented fever, incontinence, rigors with generalized myalgia in both legs and had difficulty walking. Her temperature was 38 degree celsiua. She had pain like cramp with frequent tonic spasms in the both legs. Intravenöz diazepam and intramusculer haloperidol was given to the patient but she did not respond to the treatment. Then started treatment in intensive care with the respiratory monitoring and was given intravenous midazolam infüzyon. Following 12 hours later no more tonic spasms were seen. But physical examination revealed diffuse extremity weakness and failure walking.

The repeat Gadolinium-enhanced magnetic resonance imaging (MRI) of the lumbar spine did not reveal any intraspinal abnormalities like epidural hematome or arachnoiditis. Magnetic resonance imaging of the brain showed no abnormalities. On laboratory studies, serum creatinin phosphokinase 20123 U /L (26-140) and serum myoglobin 2977 ng/ml (1466) were markedly elevated. AST $257 \mathrm{U} / \mathrm{L}$ (10-41) and lactate dehydrogenase $638 \mathrm{U} / \mathrm{L}$ (125-220) were elevated. At the same time electrolyte profile, blood urea nitrogen and creatinine were normal. Acute renal failure which is the most frequent and important complication of rhabdomyolysis didn't develop. Arterial blood gas analysis was normal. Urine myoglobin was positive and 50 red blood cells were observed per high power field on urine microscopic examination with strong positive urine dipstick for blood. Physical examination revealed diffuse extremity weakness but no other neurological findings or signs of neuromusculer diseases like dermatomyositis. Electrophysiological studies were normal. Hypothyroidism may be particularly vulnerable to this disease process. For the patient we present here, normal results for thyroid function and anti-TPO antibody levels were observed. The patient was diagnosed with rhabdomyolysis according to clinical and laboratory results and hydration therapy was started immediately. After 10 days her complaints reduced and laboratory results improved. Serum creatinine phoshokinase and myoglobin were decreased to
$1631 \mathrm{IU} / \mathrm{L}$ and $423 \mathrm{ng} / \mathrm{ml}$, respectively on $10^{\text {th }}$ day after admission. Weakness in the legs was restored and she was able to walk.

\section{Discussion}

For rhabdomyolysis; classic is muscle aches, weakness and dark tea colored urine. Some more specific symptoms include muscle tenderness, swelling, cramping, stiffness, weakness and loss of function of the relevant muscles. The most common muscle groups involved are postural muscles, such as lower back, thighs and calves. Physical examination might reveal limb induration or skin changes due to ischemic damage of involved tissues. However, there may be no signs of muscle involvement..$^{[3]}$ In our case; the patient presented with fever, incontinence, rigors with generalized myalgia in both legs and difficulty walking. Her temperature was 38 degree celsiua.

The definitive diagnosis is made by laboratory tests including serum CK and urine myoglobin. Serum CK begins to increase approximately 2 to 12 hours after the onset of muscle injury, peaks within 24 to 72 hours, and then declines gradually in 7-10 days. CK level higher than 5 times of its normal value is accepted by many authors as diagnostic criteria. ${ }^{[4]}$ Myoglobolinuria is pathognomonic to rhabdomyolysis, but is not necessarily visible. Serum myoglobin levels increase and decrease much faster than CK levels (in 1 to 6 hours), thus have a low negative predictive value and can not be used as a ruling out test. ${ }^{[5]}$ In our case; serum creatinin phosphokinase 20123 U /L (26-140), serum myoglobin 2977 ng/ml (14-66) were markedly elevated.

Direct muscle injury is the most common cause of rhabdomyolysis, but a number of other causes are possible: hereditary enzyme disorders, drugs, toxins, endocrinopathies, malignant hyperthermia, neuroleptic malignant syndrome, seizures, heatstroke, hypothermia, electrolyte alterations, diabetic ketoacidosis and nonketotic hyperosmolar coma, severe hypothyroidism or hyperthyroidism and bacterial or viral infections $^{[6]}$ In our patient, common causes for rhabdomyolysis including trauma, infection, connective tissue disease, drug overdose, exercise, metabolic disorder and sepsis were either excluded or not evident. Therefore, epidural steroid injection was thought to be responsible for the development of rhabdomyolysis. 
The exact pathogenesis of rhabdomyolysis in epidural steroid injection is not clear, two possible mechanisms have been postulated: direct toxic invasion of muscle because of the drugs which we used during the procedure ${ }^{[7]}$ or frequent tonic spasms in the both legs continuing twelve hours complicating rhabdomyolysis. Extensive muscle damage could accompany frequent tonic spasms. Hypoxia causes contracted capillaries, reduced muscle blood supply and finally results in lysing muscle cells and muscle cell damage ${ }^{[8]}$ Various drugs, such as corticosteroids, immunosuppressants, salicylates, fibrates, antibiotics, chemotherapeutic agents, antidepressants, antipsychotics and anesthetics have been associated with rhabdomyolysis, not only in toxic, but also in therapeutics doses. In our case we used dexamethazone.

Post-operative rhabdomyolysis is a well-known complication, especially after bariatric, renal, neurosurgical, cardiac and orthopaedic surgeries. Prolonged duration of surgery is a well recognized risk factor in the development of rhabdomyolysis. ${ }^{[9,10]}$ Surgical positioning is also important. Various case reports describe rhabdomyolysis after prolonged surgery in different positions. ${ }^{[1]}$ Also,diabetes and hypertension may increase the risk of rhabdomyolysis by leading to chronic microcirculation abnormalities. This leads to a higher susceptibility to perfusion problems and is a predisposing factor for rhabdomyolysis. In our case surgical position was prone, ischemia of the muscles could result from either compression of the large vessels in the abdomen and pelvis or direct pressure on the muscle leading to hypoperfusion. But in our case duration of epidural steroid injection is about five minutes and tourniquet not used and during the procedure her vital signs were within the normal limits. Therefore, we can not say rhabdomyolysis is related to technic.

Although epidural injections are safe, they are not devoid of complications. Subdural and epidural hemorrhage,epidural abscess have been reported following the epidural injections. Adhesive arachnoiditis may result from the solvent of depo steroid polyethylene glycol. ${ }^{[12]}$ In the setting of the febrile episodes or new muscle symptoms the complications of the epidural injection should be kept in mind by the treating physicians. The laboratory abnormalities like eleveted creatin kinase, myoglobine and electrolits may be indicator of rhabdomyolysis.

\section{Conclusion}

As the number of injections and interventions in the management of the back pain and lumbosacral radicular pain is increasing annually, the pain physicians and doctors who are involved in the care of these patients need to be aware of complications such as rhabdomyolysis.

\section{Informed Consent: Written informed consent was obtained from the patient who participated in this study.}

\section{Conflict-of-interest issues regarding the author- ship or article: None declared.}

\section{Peer-rewiew: Externally peer-reviewed.}

\section{References}

1. Manchikanti L, Datta S, Gupta S, Munglani R, Bryce DA, Ward SP, et al. A critical review of the American Pain Society clinical practice guidelines for interventional techniques: part 2. Therapeutic interventions. Pain Physician 2010;13(4):E215-64.

2. de Meijer AR, Fikkers BG, de Keijzer MH, van Engelen BG, Drenth JP. Serum creatine kinase as predictor of clinical course in rhabdomyolysis: a 5-year intensive care survey. Intensive Care Med 2003;29(7):1121-5. [CrossRef]

3. Keltz E, Khan FY, Mann G. Rhabdomyolysis. The role of diagnostic and prognostic factors. Muscles Ligaments Tendons J 2014;3(4):303-12. [CrossRef]

4. Brancaccio P, Lippi G, Maffulli N. Biochemical markers of muscular damage. Clin Chem Lab Med 2010;48(6):757-67.

5. Kenney K, Landau ME, Gonzalez RS, Hundertmark J, O'Brien K, Campbell WW. Serum creatine kinase after exercise: drawing the line between physiological responseand exertional rhabdomyolysis. Muscle Nerve 2012;45(3):356-62.

6. Cervellin G, Comelli I, Lippi G. Rhabdomyolysis: historical background, clinical, diagnostic and therapeutic features. Clin Chem Lab Med 2010;48(6):749-56. [CrossRef]

7. Ogoke BA. Caudal epidural steroid injections. Pain Physician 2000;3(3):305-12.

8. Elmacı AM, Akın F, Aksoy E. Acute kidney injury due to rhabdomyolysis after status epilepticus: Two pediatric case reports. J Clin Exp Invest 2013;4(4):517-20. [CrossRef]

9. Glassman DT, Merriam WG, Trabulsi EJ, Byrne D, Gomella L. Rhabdomyolysis after laparoscopic nephrectomy. JSLS 2007;11(4):432-7.

10. de Oliveira LD, Diniz MT, de Fátima H S Diniz M, SavassiRocha AL, Camargos ST, Cardoso F. Rhabdomyolysis after bariatric surgery by Roux-en-Y gastric bypass: a prospective study. Obes Surg 2009;19(8):1102-7. [CrossRef]

11. Hooten WM, Kinney MO, Huntoon MA. Epidural abscess and meningitis after epidural corticosteroid injection. Mayo Clin Proc 2004;79(5):682-6. [CrossRef] 